\title{
The use of metaphors in Narrative Research in exploring and describing experiences of adolescent male orphans affected by HIV and AIDS
}

\begin{abstract}
Authors:
Juanita Loubser ${ }^{1}$

Julian C. Müller ${ }^{1}$

Affiliations:

${ }^{1}$ Department of Practical

Theology, University of

Pretoria, South Africa

Note:

This article is published in the Section Practical Theology of the Society for Practical Theology in South Africa.

Correspondence to: Julian Müller

Email:

julian.muller@up.ac.za

Postal address:

PO Box 626, Wapadrand,

Petoria 0002, South Africa

Dates:

Received: 01 Dec. 2010

Accepted: 27 May 2011

Published: 10 Nov. 2011

How to cite this article: Loubser, J. \& Müller, J.C. 2011, 'The use of metaphors in Narrative Research in exploring and describing experiences of adolescent male orphans affected by HIV and AIDS', HTS Teologiese Studies/Theological Studies 67(2), Art. \#1009, 9 pages. http://dx.doi.org/10.4102/ hts.v67i2.1009
\end{abstract}

(C) 2011. The Authors. Licensee: AOSIS OpenJournals. This work is licensed under the Creative Commons Attribution License.
This article relates to the primary study which aimed at addressing uncertainties about the type and nature of the relationship between the human immunodeficiency virus (HIV) and acquired immune deficiency syndrome (AIDS) and adolescent male orphans affected by this disease and all its aspects, such as poverty, exposure to crime and stigmatisation, and the lack of parental figures - more specifically, the absence of the father figure. Subsequently, this study aimed at dissecting the orphan's life experiences in the midst of HIV and AIDS and explored ways in which these experiences influence his sexual and power relations with women and his role as future father and husband in the absence of a father figure (or male role model). Moreover, the researcher explored ways in which these past and future narratives influence or affect the male orphan's view of and relationship with God, or whether it is rather this view of and relationship with God that influence and affect his relationship with his past narrative and writing of his future narratives. Research methods from the qualitative and case study research design and, more specifically, from postfoundational practical theology and narrative therapy, were employed in exploring the above issues. With the use of the metaphor of Tree of Life and the David narrative, the researcher journeyed with the co-researchers in the construction of a preferred alternative narrative, which in turn functions as a guiding metaphor for aspiring to the future and living their lives in a preferred and satisfying manner. Therefore this article explains the use of these metaphors during the seven movements of Postfoundational Practical Theology and shows how these metaphors succeeded in assisting the co-researchers with externalising aspects of their problem-saturated narratives, identifying unique outcomes amidst these narratives, and developing alternative narratives that serve as a vehicle for change and creating hope amidst a context of seeming despair.

\section{Introduction}

According to the joint United Nations Programme on HIV and/or AIDS (UNAIDS) report (2010) on the global acquired immune deficiency syndrome (AIDS) epidemic, 33.3 million people were living with the human immunodeficiency virus (HIV) and AIDS by the end of 2009 worldwide (UNAIDS 2010:23). Unfortunately sub-Saharan Africa still seems to bear an '... inordinate share of the global HIV burden' (UNAIDS 2010:25), where South Africa alone harbours 5.6 million HIV positive people (Statistics South Africa P0302:6).

In sub-Saharan Africa, women are drastically more affected and infected by HIV and AIDS than men. Various reports and articles confirm this and emphasise the fact that in sub-Saharan Africa '... young women aged 15-24 years are as much as eight times more likely than men to be HIV positive' (UNAIDS 2010:10). Therefore it has been found that by 2009, 60\% of HIV positive people in sub-Saharan Africa were women (cf. UNAIDS 2010:25). Additionally in South Africa it has been found that ' $[A]$ lmost one-in-three women aged 25-29, and over a quarter of men aged 30-34, are living with HIV' (Human Sciences Research Council 2009) and that in sub-Saharan Africa '... 80\% of all women in the world living with HIV live in this region' (UNAIDS 2010:121). These statistics are significant as it shows that sexual and physical violence against women, in South Africa, is very much prevalent (cf. Jewkes 2009). Disturbingly it has been found that '... more than four-in-ten South African men' have been found to be physically violent to an intimate partner, and more than a quarter of South African men have raped a woman, which brings the total to one-in-twenty men committing rape in 2009 (cf. Jewkes 2009). Moreover, Jewkes (2009) states that '... the generally high HIV prevalence among all men surveyed means there is a good chance that a man who commits rape has HIV'.

The fact that the mortality rate for HIV positive women is higher than for men affects not only the statistics, but also leaves thousands of children to fend for themselves. As a result of these high maternal deaths, it has been found that there were 1.9 million AIDS orphans by 2009 (cf. UNAIDS 
1010) and that '.. the HIV/AIDS epidemic is responsible for half of the country's orphans' (HIV and AIDS and STI Strategic Plan for South Africa 2007-2011).

Above and beyond the direct consequences of the HIV and AIDS epidemic, lays the devastation of the family structures that a society must bear. The family structure as an institution is naturally a safe harbour for children to be nurtured and guided into ways of being, a space where gender and personal identities can be developed and where they make sense of themselves and the world around them (cf. Barolsky 2003:14). However, in the context of HIV and AIDS, where important care givers fall ill, where parents die and children are orphaned, the family structure is placed under an immense burden and its ability to '... operate as an agent of socialisation, economic support, nurturance and care' is compromised (Barolsky 2003:14).

The fragmentation of family structures can only partly be explained by mothers who die because of opportunistic diseases. The fact is that most children are left fatherless before losing their mothers due to HIV, which puts even more strain on women to cope, and might even play a role in furthering the spread of this horrible disease, as Barolsky (2003:15) states: 'The epidemic, with its disproportionate impact on women, will therefore have a particular effect on the ability of the family to adapt to the demands of the epidemic'.

Thus, at its core, the battle against HIV and AIDS entails many unjust and unequal social practices that increase women's vulnerability to HIV and AIDS. The agents of these practices are often men, as traditional concepts of masculinity inherent in sexuality and within the traditional family structures are still the dominant discourse (cf. Rao Gupta 2000:1-2). Despite this, many men do not step up to their responsibilities as fathers and desert their families, as Mtimkulu (2006:28) states: 'It has been estimated that about $50 \%$ of African men are absent fathers'. In turn, the high rate of father absence is an impediment to proper child-raising and has many negative psychosocial consequences on a child's development: 'The absence of the father means that children are unable to develop properly on many levels: psychologically, materially, emotionally, cognitively and physically' (Mtimkulu 2006:39).

There are several studies focusing on the plight of women affected and infected by HIV and AIDS, and rightly so, but this raises the question of where the African males' voices are in this narrative. Whilst the world is overtly making an effort to study women and the ways they are exploited and abused by men, we are ignoring or perhaps missing men's active role in this scenario. I have found that many studies speak on men's behalf and that they come to seemingly impartial conclusions, which nevertheless blame men as the perpetrators in the HIV and AIDS global narrative. Naidoo, Matebeni and Pietersen-Snyman (2004:46) also found that much literature studies have been done regarding women's experiences, but it seems that either men are not seen as vulnerable, or no attempts have been made as yet to listen to their stories which might contain issues of vulnerability or the like.

This is exactly where the vacuum in the research of gender and HIV and AIDS lies. The fact is that we are so busy with the feminisation of HIV and AIDS that we tend to forget that on the other side of the pendulum lies another important factor that forms part of the equation, namely men.

From the aforementioned statistics and findings, several questions came to the mind of the researcher regarding HIV and AIDS orphaned boys and their relations to and within the HIV and AIDS context; questions such as: what are adolescent male orphans' psycho-social and spiritual experience of the HIV and AIDS environment and the loss of their parents and what psychosocial and spiritual coping styles have they employed to survive within this context? What narratives have they written in understanding the loss and/or death of their parent(s), and what future narratives are they writing for themselves from within this context? How does their experience within the aforementioned stated context influence their future narratives about sexual and power relations towards women and how might these narratives contribute to the exploitation and abuse of women, and subsequently to the spread of HIV and AIDS? How does this experience influence their future narratives as future fathers and husbands, in the absence of such a father figure? Finally, how does this experience of growing up without a father figure influence their view of and relationship with God, who is seen as a Father Figure Himself? Do their relationship with God act as a 'coping' style with the loss and/or death of parent(s) and future challenges they might face?

In essence this study aimed at exploring and describing these unique and different experiences of orphaned boys affected by HIV and AIDS. The researcher believes that the study into the world of orphaned boys and their experiences of and with HIV and AIDS opened up a whole new world of insights to us as it is these boys who will become men, who will become husbands and fathers. By moving closer in understanding the contributing factors of future men and their behaviour, of their thoughts, beliefs and experiences of this pandemic, amidst this pandemic, as well as their view of and in the absence of a father role model, we might just have moved a step closer to winning this battle.

\section{Research approach}

This research followed the design of the qualitative research approach, which means that specific theories both underpins and motivates the methodological approaches which have been followed. Qualitative research is very much interested in the perspectives of the co-researchers; their experiences of phenomena and their understanding of their experiences of specific phenomena (cf. Struwig \& Stead 2007:12). Therefore all activities included within the qualitative research design are aimed at exploring individual experiences and understandings. Based on these assumptions the researcher 
and the co-researchers engaged in various opportunities for conversation which increased the understanding of the researcher and assisted in the description of understanding.

Within the qualitative research strategy, the researcher has chosen the case study design as point of departure when collecting data. Because the researcher was specifically interested in describing and understanding an individual's experience of a phenomenon, the case study design proved most useful for the purposes and interests of this study, as it is also one of the few designs which can be utilised to study a single instance or an individual's personal experience and behaviour. The case study design is generally not aimed at the generalisation of results; therefore this research study also did not aim at comparison, testing or generalisation of results or findings.

In using the case study design the researcher utilised various methods of data collection, such as group interviews and individual interviews, the use of individual case studies, the development of a theme-based workbook, collateral observation, participatory observation and literature study.

Congruent with the case study design, participants were selected according to the nonprobability sampling method (cf. Whitley 2002:394), because of the unavailability of a list of HIV and AIDS orphans. The researcher selected two nongovernmental, community-based and faith-based organisations who work specifically with orphaned and vulnerable children affected by HIV and AIDS.

At the end, seven participants were chosen and invited to take part in this study as co-researchers. Five participants were from Pen, of whom two moved to Thembisa in the third year of the study, one moved to a flat in the inner city of Pretoria and two resided in Precious Pearls, a safe house of the organisation Pen. All five boys had resided in Precious Pearls at the start of this study from 2007 to 2009, but only two remained by the end of this study. The two remaining participants are under the care of Heartbeat and reside in Thembisa; one lives with his grandmother, whilst the other lives with an aunt. Eight of the boys chosen as co-researches have lost their mothers due to death at least four years prior to this study. Six of the boys were abandoned by their fathers, two boys (twins) have lost their father during a gun fighting incident when they were very young and one lost his father due to an illness. Subsequently all the boys, except one are double orphans.

Data analysis did not happen in isolation, but in collaboration with the co-researchers themselves. It is important to note that data analysis was not the primary goal of the research process and did not naturally follow data collection; instead, understanding was the primary goal and was reached as the researcher and the co-researchers deconstructed personal narratives and developed alternative narratives. Therefore, this research study did not focus as much on analysis as it did on the description and understanding (meaning-making) of experiences and narratives.
Various theoretical paradigms and models were utilised to assist in the process of meaning-making and understanding during both the data collection phase and the analysis phase, and indicate the manner in which the researcher views the ontology and epistemology of this research context. The researcher did qualitative postmodern and postfoundational research, based on the models of the narrative approach and the seven movements of the postfoundational notion of practical theology, which will be discussed briefly in this article.

\section{The postfoundational notion of practical theology}

In assisting with the construction of alternative narratives, or preferred narratives, methods of the postfoundational notion of practical theology were employed.

Gerkin (1991:13) states that practical theological inquiry is concerned with both theological as well as practical considerations. This means that through the imperatives of practical theology, we are interested in serving people and their concerns through their daily communication and relations within a specific cultural and social setting, by showing continuity between the story of the Bible and the story of the particular person, at a particular place, within a particular point in time. Practical theology therefore aims at acting in the paradigm of the social world, through the paradigm of Christian theology, traditions and language.

Pattison (2000:42) in turn states that practical theology is an enterprise which gives special attention to specific situations, and is therefore known '... for the delicacy of its distinctions not the sweep of its abstractions' (Geertz 1991:25). Pattison (2000:42) furthermore states that practical theology emphasises the seeing and understanding, first listening and then carefully speaking; it is sensitive to context and situation and therefore, modest in its claims and postulations.

Müller (2005:73-75) states that adding the notion of postfoundational rationality to the practice of practical theology, constitutes a rediscovery of the basic and most simple imperatives of practical theology. These imperatives aim to '... move beyond the modernistic boundaries of practical theology, which tends to be formal and rationalistic' (Müller 2005:73-75); whilst at the same time avoiding the relativistic and dangerous tendencies of antifoundationalist theories.

In essence the postfoundational notion of rationality does not only influence practical theology's philosophy, but also its methodology: 'This practical theological narrative is not only a paradigm-story, but also a method-story' (Müller 2005:86). If this philosophy does not eventually move into methodology, it will contradict the imperatives of the model. Therefore, a postfoundational notion of rationality provides us with an integrative narrative which includes the theologian in both processes of 'story-telling' and 'story-making' (cf. Müller 2005:86). This participation should be very sensitive and descriptive in the deconstruction of problematic discourses, 
as well as in its development of alternative discourses or narratives (cf. Müller 2005:86). Thus, with the use of this model, a prerequisite, before moving into method, would be to attain a certain attitude of sensitivity and discretion, as well as openness to the context and being unbiased so that specific cues of discourse can be heard.

This type of theological reflection or attitude circles around three specific movements (cf. Van Huyssteen 2004: Lez Eyzies Symposium):

First, an acknowledgement of contextuality, the role of interpreted experiences and the influence of disciplinary tradition in the values people hold, and how these values are used to reflect upon God and His presence in the world.

(Müller 2005:76-77)

Secondly, an increased awareness of an epistemic duty which extends the boundaries of, and our boundedness to our specific discipline, community, groups, cultures, et cetera, so that we can partake in a reflective and effective interdisciplinary discussion, whereupon shared resources can be discovered (cf. Müller 2005:76-77; Van Huyssteen 1999).

Finally, these newly discovered shared resources can be expressed most effectively with the use of the notion of transversality:

In the dialogue between theology and other disciplines, transversal reasoning promotes different but equally legitimate ways of viewing specific topics, problems, traditions, or disciplines, and creates the kind of space where different voices need not always be in contradiction, or in danger of assimilating one another, but are in fact dynamically interactive with one another

(Müller 2005:76-77)

The use of the notion of transversality is most useful to practical theology because it creates new possibilities for discussion through the imperatives of reflection and action, whilst at the same time keeping us humble in our endeavours as we gain new respect for various and diverse reasoning strategies (cf. Schrag 1992:148ff; Welsch 1996:764ff; Müller 2005:77). It guides us by keeping us concrete, local and contextual whilst reminding us of how our episteme are shaped by tradition (cf. Müller 2005:77).

Subsequently a postfoundational notion of practical theology allows the researcher to be embedded in a specific context so that true understanding can be reached, but also allows us to move beyond a specific context so that we can understand how wider macro discourses influence our current narrative (cf. Demasure \& Müller 2006:417).

Browning (1991:34) states that a truthful practical theological method will entail a definite and purposive motion from context to theory and back to context again. Müller (2005:78-79) refers to this methodological process as '... the circle of practical wisdom' and accordingly developed several minimum requirements for doing research in the discipline of postfoundational practical theology, so that we can reflect in a meaningful manner on the experiences of the presence of God. Accordingly, practical theology must always be locally contextual, socially constructed, directed by tradition, explorative of interdisciplinary meaning and pointing beyond the local (cf. Müller 2005:78).

\section{The seven movements of practical theology}

The requirements of a postfoundational notion of practical theology have been extended into seven movements that, when conducted, result in achieving the outcomes of the minimum requirements for a postfoundationalist practical theology (cf. Müller 2005:78). In addition, specific methodological guidelines were developed for each movement that was conducted in the context of this study (cf. Müller 2005:82). Take note that each movement is accompanied by specific methods that were used to collect, describe and/or interpret the data. Each movement is represented by an appropriate metaphor, which elaborates on the primary metaphor of David and Goliath and which describes the nature of each movement metaphorically as it applies to the research process and the elaboration of 'thick' descriptions.

This study has divided the reporting of the research process into the five requirements of a postfoundational notion of practical theology.

The first requirement for a postfoundationalist practical theology is that of being locally contextual and entails the context and interpreted experiences within that context. Three movements were developed for directing exploration of this requirement:

1. A specific context is described.

2. In-context experiences are listened to and described.

3. Interpretations of experiences are made, described and developed in collaboration with co-researchers.

The second requirement is that of being socially constructed, and refers to the traditions of interpretations. This requirement is elaborated and directed in movement number four and five:

4. A description of experiences as it's continually informed by traditions of interpretations. To be directed by tradition, is the third requirement and corresponds with God's presence, and is explored in the fifth movement.

5. A reflection on the religious and spiritual aspects, especially on God's presence as it is understood and experienced in a specific situation.

After reflecting on God's presence, this reflection and developed understanding must be thickened through interdisciplinary investigation, where the practical theological researcher must explore interdisciplinary meaning, as to meet the fourth requirement, is directed by movement six:

6. A description of experience, thickened through interdisciplinary investigation.

Finally, the last requirement asks for a movement beyond the local and is directed by the seventh movement of doing postfoundational practical theological research: 
7. The development of alternative interpretations that point beyond the local community.

Each movement is accompanied by specific methods which were used to collect, describe and/or interpret the data.

\section{Metaphor of narrative}

The idea of narrative as a functioning frame of reference in organising one's experiences and understandings emerges directly from the paradigm of social constructionism. The idea of narrative, however, was already visible in the postmodern theory of Jean-Francois Lyotard (1984:29f), where he proposed narrative and scientific knowledge as two different types of discourses. He stated that both these discourses have legitimate functions, but that only the narrative provides knowledge that cannot be gained in any other way and as thus can also legitimise scientific knowledge, without the use of the former universal and absolute grand narrative (cf. Lyotard 1984:18ff; Van Huyssteen 1999:34). Therefore, already in the emergence of postmodernism, the idea of narrative in the construction of an alternative epistemology was proposed, as it can serve as a platform where a multitude of realities and knowledge can come together to create holistic understandings.

Paul Ricoeur also acknowledges the usefulness of the model or metaphor of the narrative, by stating that stories provide an opportunity for both the creation of identity and the transformation thereof (cf. Demasure \& Müller 2006:412). He affirms this transformative quality of the narrative by explaining that it is made possible through the way in which facts and events are selected and linked. This process of selection and connection is based on many possibilities available to the narrator and happens by chance, not because it is the only way that these facts and events can be selected and connected, therefore stating that the content of a narrative is not arranged as a cul-de-sac. Thus, the model of a narrative provides us with many possibilities of construction (cf. Demasure \& Müller 2006:412).

Because of this constructive nature inherent in narratives, it becomes reflective of the dominant discourses of one's society or social group. People construct stories about themselves and their experiences, as well as the meaning of these experiences for them in a specific context, influenced by various traditions. Thus, when a narrative is told, multiple dimensions of influence are unveiled. Demasure and Müller (2006:412) confirm that narratives reveal much more than just concepts; they contain the life story of a person and when an inquiry is made about a person, that life story is put on the centre stage. Therefore, each person has a narrative identity, which serves as a resource centre for understanding events and experiences, both in the past and the future.

Demasure and Müller (2006:413) mention the importance of the context of both the narrator and the author of a narrative, by using the notion of 'horizon', a concept coined by Gadamer (1982). They state that both the narrator and the listener are marked by their own embedded context, which in turn means that this context affects the way the story is told and interpreted.
Gerkin (1991:20) explains that Gadamer first used the concept of the fusion of horizons in explaining how text, or other discourses such as the narrative, is interpreted by different people. The term 'horizon' implies that '... every humanly constructed text or artefact ... emerges from, and is an expression of a horizon of understanding or meaning' (Gerkin 1991:20). Therefore, both the narrator (the person who constructed the narrative) and the person who aims at understanding this narrative, is guided by a specific and different horizon of meaning.

This indicates another important directive of a narrative that allows for multiple understandings and interpretation, which in turn guide a person to the construction of a subjective meaning-making narrative. Therefore, people are not bound by the idea that only one interpretation is correct and acceptable and that their thoughts and actions must be directed by this universally accepted notion of meaning and purpose, but that they can attain the freedom of choosing an understanding which will function as a motivator of transformation and change, thereby increasing the possibility of reaching one's full potential. People are also liberated by the possibility of change - the idea that one's narrative is not carved in stone. Thus, instead of a clash of horizons, such as presented by modernism, a fusion of horizons is now proposed (cf. Demasure \& Müller 2006:413).

Thus, narrative therapy aims at guiding a client in deconstructing a self-negating narrative with the use of deconstructive listening and deconstructive questioning methods. He or she then accompanies the client in the process of externalising the problem and searching for unique outcomes, so that eventual new interpretations of a narrative are possible. Narrative therapists believe that these new interpretations should be privileged over other narratives, before they can act as a guiding metaphor for living one's life. The end result of successfully establishing and maintaining an alternative dominant narrative and therefore alternative interpretations, is the reshaping of a person's outlook, attitudes and future behaviour (cf. Goldenberg \& Goldenberg 2008:367).

\section{The Tree of Life narrative}

Because of the narrative significance and possibilities inherent in the metaphor of the Tree of Life, the researcher of this study and her colleague decided to use this metaphor in similar ways. Ten participants (co-researchers) were invited to a weekend break-away in discussing the items contained in the developed Tree of Life (TOL) booklet.

Firstly, the Tree of Life metaphor included submetaphors such as the roots, trunk, branches, leaves and bugs to indicate specific life events and significant people. Added to this metaphor was the ground in which a tree is tightly and safely grounded. In this manner the roots indicated the history of the children's lives, their familial history, their place of birth and their ancestors. The ground out of which the tree grows and in which it is tightly grounded, referred to the 'nutrients' a tree receives, the soil or the ingredients that make it grow. Therefore the ground referred to one's spirituality, one's 
story of createdness, or to God. The trunk of a tree referred to one's skills, abilities and talents, whilst the branches in turn referred to one's hopes and dreams that can 'reach up to the $\mathrm{sky}^{\prime}$. The leaves referred to the people in one's life: the green leaves might indicate living people, whilst the withered leaves refer to those significant people whom a person has lost. The fruits or blossoms that a tree carry, in turn referred to the gifts or things we have received from other people, such as love or kindness, whilst the bugs referred to those people who have not been kind to us. Finally, we referred to the storms trees can experience, which symbolise difficult times people experience, such as death, illness or poverty.

The sessions were started by discussing the metaphor of a Tree of Life and its accompanied submetaphors. The children were then asked to draw their own trees of life, by including all the submetaphors. It was pertinently stated that the children can include anything else they feel significant or meaningful to their story, thereby creating a space where they can use their own creativity. Afterwards, everyone had an opportunity to discuss their Tree of Life.

Everyone then had an opportunity to put their trees on the wall, signifying that together they form a forest that protects each other from the storms. Thereafter, everyone also had an opportunity to discuss some storms they have experienced, as well as the talents, skills or abilities they used to combat the effects of these storms. The discussion went deeper by allowing the children to identify the people who support them through these storms and thank them by writing a letter of appreciation; whilst also identifying people whom they have supported through similar storms. This illustrated the concept of 'Ubuntu', or 'being there for each other' and that they too can be active agents in helping other trees grow.

Finally, we discussed the metaphor of fruits or blossoms, indicating the gifts we receive from other people. Each child had an opportunity to think about and name the gifts they have received. This was followed by an activity where everyone sat in a circle and a piece of paper was sent around with each child's name on it. Everyone had to write a compliment about that person. Afterwards, each child received his or her compliment paper and read it out loud to the group. The children reported afterwards that this activity has shown them that they too are special and unique.

The use of this metaphor assisted in the empowerment of the children, as they used this opportunity to connect all the seemingly unrelated events and people in their lives into a holistic whole, which gave them a 'birds-eye view' of their lives. In doing this they gained control over their own lives - a loss of control is usually signified by being lost in detail, or in chaos. This gaining of control, or empowerment, gave them the strength to restructure and re-design a new future narrative, which does not ignore their past and people in their lives, but incorporates them so that the future narrative becomes relevant, real and therefore much more attainable than some 'dream' developed in fantasy. This metaphor therefore successfully helped the children to think of their lives as a story, thereby creating a central role for them as active actors in their own life stories, giving them control to position themselves and the events in their stories where they felt fit and, finally, to relate all the events and people in such a way that understanding and meaning were attained.

\section{The David narrative}

An analogy between the narrative of the co-researchers and the story of the biblical David was proposed by way of illustrating metaphorically the subjective meaning of events (plots) in their narratives. The plots in the narrative of David were compared metaphorically to the plots of both the contextual and spiritual narratives of the co-researchers. This illustration was used as a way of externalising the problem and developing a unique outcome so that an alternative story could be created.

In the same way that the Tree of Life metaphor encouraged a cyclic movement of relevance from the past, present and future, the narrative of David also metaphorically or homiletically assisted in connecting Christians' current life stories with the narratives of the Christian community that are embedded in the narratives of the Bible. In the narrative of David, the actors of the story were specified as metaphorical role models and the metaphors were fixed in three time lines (past, present and future). This allowed for a cyclic narrative movement between the story of God with his people and the story of the co-researchers. The primary reason for doing this was to offer pastoral care to the co-researchers through assisting them in giving meaning to their life stories by connecting their life stories with the story of faith which seems to act as a motivator in creating alternative meaningful and purposive life stories. Furthermore, when the connection between the two stories was made, the pastoral therapist assisted them in deconstructing their past stories in the paradigm of the deconstruction of the stories of the Bible in order to help them create an alternative narrative. Charles Gerkin (1992:103) states that the function of the pastor (or pastoral therapist) lies in the action of offering a '... context of ultimate meaning with which life can be lived'.

Besides the metaphorical and even homiletic significance of the narrative of the historical David, is also a hermeneutical significance given by Walter Brueggemann. Brueggemann (2002:1-2) states that we are not as much interested in the historical David, because we can in fact not isolate this David and identify him as the 'real' David. All we have of David is Israel's imagination that constructed David through literature and we can, in fact, not get behind this literary construction of David, by Israel. This also makes us more aware of the fact that we ourselves are nothing more than imaginary constructions. Although the title of the study suggests that we are interested in adolescent male orphans affected by HIV and AIDS, the fact is that in our minds we have already constructed an idea of these orphans in general, hence the interest in these particular individuals' viewpoints. Therefore we have multiple views of one person, and the aim of this study was to get behind this imaginary construction, 
to understand how these individuals experience their world, so that we as observers and subjective participators can move away from our generalisations and stereotyped assumptions with the aim of understanding with empathy. Only with an empathetic understanding can we get behind these imaginary constructions. Getting behind these imaginary constructions means that we will not necessarily get behind the factual and historical co-researchers, but rather the meaning behind their, our and others' meaning and interpretations of the collective imaginary constructions. As a matter of fact, it is these imaginary constructions that are lived and retold; therefore, understanding these becomes more important than understanding the factual and the historical.

Brueggemann (2002:2) postulates an exploration of ways in which we can participate in the imaginary construction of David, so that we can both participate in the further creation of the imaginary construction, and also be addressed by it. When listening and deconstructing the stories of our coresearchers, we are made aware of our deep prejudices and biases regarding African men in the South African context, thereby addressing these prejudices and biases and even stereotyped assumptions. Thus, in the process of creation and deconstruction, we are forced to revise our imaginary construction of African men, so that we can come to a better understanding and participate in the reconstruction of our own narratives. This will enable us to participate in the construction of their narratives, whilst at the same time learning about ourselves from their narratives.

\section{The seven movements of practical theology illustrated and applied through metaphor}

The metaphor of David and Goliath was divided into different sections in order to represent the postfoundational idea of practical theology and its seven movements. These submetaphors also assisted in a better understanding of the research process and the development of alternative narratives, and helped the co-researchers in externalising the different challenges they face, and identifying the unique outcomes through the telling and re-telling of their narratives.

\section{The Battlefield}

The first movement is labelled 'The Battlefield' and is concerned with the description of the context, as experienced by the co-researchers, infused with the different elements that influenced the writing of their narratives. The context of the co-researchers was first described in terms of the most significant events embedded in this context, which have an influence on the construction of their narratives. This movement was named 'The Battlefield', because it refers to the description of the stage upon which the battle will take place. This analogue was specifically chosen as it became apparent that the co-researchers of this study are indeed fighting a battle. As with any war, it is to one's advantage to know the battlefield - to know where your enemies come from, what shelter is provided, and what armour is available from the battlefield - hence the activity of sending a scout to explore the battlefield and the enemy. Therefore, these movements acted as a scout in exploring our battlefield.

From the initial narratives told by the co-researchers, certain themes were identified during the exploration of the 'battlefield'. Both the researcher and the co-researchers then aimed at understanding these themes within the battlefield through sharing stories, experiences and subjective understanding; by incorporating the opinions and views of variousliteraturesand throughinterdisciplinary conversation. Some of the identified and explored themes included: parental loss, orphanhood and abandonment; gender and sexuality; poverty; poor psychosocial development, and HIV and AIDS within informal settlements.

\section{The narratives of (post)modern-day Davids, fighting their (post)modern Goliaths, in the context of their Trees of Life}

The next two movements, namely listening to and describing in-context experiences, as well as making and describing interpretations of experiences in collaboration with co-researchers, were labelled 'The narratives of (post) modern-day Davids fighting their (post)modern Goliaths in the context of their Trees of Life'. Here a report on the narratives of each (post)modern-day 'David', as subjectively experienced, was given. Each narrative was signified with the use of a metaphorical African pseudo name (chosen by the co-researchers) and was later used as a point of departure in identifying and thickening unique outcomes. These pseudo names were Molimi, meaning 'farmer', Manqoba meaning 'victor', and Kgotoso meaning 'peace'.

\section{Understanding the battle (weaponry, personal armour and combat training)}

Movement four was concerned with a description of experiences, as it is continually informed by traditions of interpretations, and indicated the various discourses underlying the context, which serve as traditions of interpretations. This study was particularly interested in discourses that influence the construction of the selfnarrative in relation to future-related role expectancy and responsibilities, gender identity formation and religious relations, which might or might not influence the spread of HIV and AIDS. From these narratives several discourses or traditions have been identified, which were described and elaborated with the use of additional related literature, which in turn assisted in understanding the 'battle' that is to be faced.

The metaphor of 'weaponry' was also used here as an indication of the various discourses informed by traditional interpretations, within the boys' local context (battlefield). Weaponry can both be advantageous or disadvantageous, depending on the person's position in the battlefield and in the army. Some of the weaponry (or themes) identified, explored and discussed included concepts related to masculinity, such as: 
- sexuality

- HIV and gender

- money

- protection

- the concept of being a real man

- the role of a 'father'

- violence

- occupation

- facing problems or taking responsibility.

The 'personal armour' of battle referred to the 'covering' that functions as protection during battle. It metaphorically refers to those characteristics incorporated into the narrative of the self that assist the co-researchers in constructing a narrative that will help them understand and make sense of their experiences. It also assists in the creation of a future narrative, with this constructed self as the primary actor of this narrative. The incorporation of these characteristics also acts as a protective shield against attacks and challenges experienced, in order to maintain the coherence of the constructed narrative; whilst the collection of various items that make up the identity provide a person with a sense of continuity with his or her past, as well as direction for the future (cf. Marcia 1993:3). In this study these characteristics ('personal armour') are collectively referred to as 'identity' and the process of collecting these characteristics, as 'identity formation'. These concepts were explored by looking more closely at the nature of gender identity and the role of society and culture in the formation of such an identity.

The final consideration for understanding the battle was understanding the familial context as experienced by children, and the influence that this context has on the formation of an identity which is used to protect oneself during 'battle'. Therefore, the familial context was metaphorically referred to as 'combat training', because the family is the one place where one learns how to be and how to view the world (the 'battle'). Four themes were discussed as part of combat training, namely:

- the influence of being raised in a vulnerable family

- the effect of family incompleteness

- the five levels of interpersonal understanding of social cognition

- egocentrism as an adolescent characteristic.

\section{David's battle - God's victory}

This section investigated and reflected on the religious and spiritual aspects inherent in the narratives of the coresearchers and, more specifically, on aspects that tell us about how the co-researchers understand and experience the presence of God within their specific situation.

The metaphor 'David's battle-God's victory' has been chosen to represent this movement, because it indicates the role of God and our experience of God within our own narratives or battles. Up to this point the battle and all aspects of the human battle have been explored so that we can come to an understanding of how our daily experiences and our past relations with significant others influence our experiential world and relations with others. Therefore, movement five focused on how the co-researchers experience God and how these spiritual narratives influence the development of a future or alternative narrative. With the use of this movement, various theories regarding the development of faith, religion and a sense of morality were explored and described.

\section{Whose Son Art Thou, Thou Young Man?}

The sixth movement was concerned with giving a description of experiences which are thickened through interdisciplinary investigation. The aforementioned metaphor was chosen because of the informative nature of King Saul's question: 'Whose Son art Thou, Thou Young Man?' Hamilton (2008:260-261) states that Saul is in fact asking about David's roots, in amazement and ridicule. This corresponds with the inquisitive nature of this movement where an enquiry is made to the roots and stock of the co-researchers, from the perspectives of various scholars in different fields of social science. Part of the postfoundational notion of rationality is the idea of transversality, which explores understandings and interpretations beyond the specific and locally embedded context and discipline by engaging in cross-cultural and interdisciplinary conversation. Four conversationalists were invited from different disciplines to engage in interdisciplinary conversation with this study, based on three constructed narratives. The pseudo names of three of the co-researchers were used in constructing a summary of their narrative. These narratives were then given to the conversationalists with the aim of gathering their reflection.

\section{For the battle is the Lord's}

Movement seven enquired into the development of alternative interpretations that point beyond the local community. Here we were interested in the unique outcomes that became visible through the telling of narratives, which gave rise to the development of alternative, nonproblemsaturated narratives. The metaphor of 'The battle is the Lord's' has been chosen as this is the point in our David narrative where his narrative with God was also alternatively interpreted. David followed a journey where he was chosen by God, challenged by Goliath and King Saul, tempted by his lust, and at the end of his journey, he also came to the conclusion that '.. all this assembly shall know that the LORD saveth not with sword and spear: for the battle is the LORD'S, and he will give you into our hands' (1 Sm 17:47). By the end of this movement it became clear that the coresearchers' interpretations of their narrative also contained this element of trust and victory.

\section{Conclusion}

In using the narrative model in collecting and interpreting data, the researcher decided to specifically use the metaphor of the Tree of Life and the David narrative as analogy in guiding the co-researchers to reflect on their current narratives and in the development of a meaningful and purposive alternative narrative. This movement was motivated by the statement of Freedman and Combs (1996:1) that shows the powerful influence of the metaphors we choose, and through which we organise our lives and work, on the construction of our perceptions and subsequent behaviour. 
Demasure and Müller (2006:412) speak about the '... dialectic movement between texts with their symbols and metaphors, and the active contribution of people', which indicates that people move between various texts and their metaphors in constructing meaning and meaningful narratives, which in turn guide their perspective and understanding of their own worlds. Thus, the metaphor of the Tree of Life has been chosen as a point of departure for the co-researchers in describing their current context and experiences within this context. The Tree of Life metaphor also provided an opportunity to reflect on possible unique outcomes within this context, which were mostly filled with feelings of loss and abandonment, which in turn provided the basis for the construction of an alternative narrative, through the re-drawing of another 'Tree of Life'.

In turn, the analogy with the narrative of the biblical David provided a basis for the co-researchers to deconstruct certain discourses within their contexts, which in turn influence the construction of their future narratives as future men, husbands and fathers. Therefore, this narrative was offered as an analogy to their own lives, of how their society or community assist in the construction of gender-related, spiritual narratives.

The Tree of Life metaphor helped in the construction of a holistic life narrative where the narrative of David, in turn, showed the socio-cultural and historical constructiveness of our gender-identity narratives. In using this narrative, the coresearchers could thicken the descriptions of their alternative future narratives, in line with the methods of narrative therapy. In addition, using the characters of the narrative, such as Goliath, David and Bathsheba, the co-researchers got an opportunity to externalise the problem in the person of Goliath, to put themselves in the person of David in facing their Goliath, and externalising various 'temptations' in being a man in a specific context, in the personhood of Bathsheba.

The metaphor of the Tree of Life and the narrative of David assisted much in overcoming language barriers. In reading a story or understanding a metaphor, language becomes universal. Metaphors and narratives that contain metaphors and analogues, have the immense power of moving beyond language into a space where symbolism becomes enough to convey understanding. At the same time, however, a metaphor and narratives become a language specific to each person, where his or her own meaning is derived, despite the supposed universalism of the metaphor and narrative. Not only is a narrative reconstructed, but also the metaphor and analogies contained within the narrative.

Therefore, both the metaphor of the Tree of Life and the analogy of the David narrative served as meaning metaphors, which could be incorporated into the co-researchers' alternative narratives. These meaning metaphors enriched the understandings and meanings of the co-researchers' own lives, because these narratives are embedded within a specific context - the context of the world which maintains a tension between the past, present and future narratives of ourselves and our relations with people in this contexts; as well as the context of the story of God. In turn the story of God was made more 'real' and 'relevant' by seeing it in the light of the co-researchers' own narratives and by realising how God is involved with people whose lives are also embedded and constructed in the human world.

\section{Acknowledgements Competing interests}

The author declares that he has no financial or personal relationship which may have inappropriately influenced him in writing this article.

\section{References}

Barolsky, V., 2003, Over extended AIDS Review, Centre for the Study of AIDS, University of Pretoria, Pretoria.

Browning, D.S., 1991, A fundamental practical theology, Fortress Press, Minneapolis, $\mathrm{MN}$

Brueggemann, W., 2002, David's truth in Israel's imagination and memory, 2nd edn., Fortress Press, Minneapolis, MN.

Demasure, K. \& Müller, J.C., 2006, Perspectives in Support of the Narrative Turn in Pastoral Care, Nederduits Gereformeerde Teologiese Tydskrif (NGTT) 47(3), 410-419.

Freedman, J. \& Combs, G., 1996, Narrative therapy: The social construction of preferred realities, W.W. Norton \& Company, New York, NY.

Gadamer, H., 1982, Truth and method, Crossroad, New York, NY.

Gadamer, H.G., 1975, Truth and method, 2nd edn., Seabury Press, New York, NY.

Geertz, C., 1991, The interpretation of cultures: Selected essays, Fontana, London.

Gerkin, C.V., 1991, Prophetic pastoral practice, Abingdon Press, Nashville, TN.

Gerkin, C.V., 1992, An introduction to pastoral care, Abingdon Press, Nashville, TN.

Goldenberg, H. \& Goldenberg, I., 2008, Family therapy: An overview, Thomson Brooks, Belmont, CA

Government of South Africa, 2007, HIV and AIDS and STI Strategic Plan for South Africa 2007-2011, viewed 20 May 2011, from http://www.info.gov.za/otherdocs/2007/ aidsplan2007/index.html

Hamilton, V., 2008, Handbook on the historical books, Baker Academic Grand Rapids, MI.

Human Sciences Research Council, 2009, 'South African National HIV Prevalence, Incidence, Behaviour and Communication Survey 2008: A Turning Tide Among Teenagers?', viewed 20 May 2011, from http://www.hsrc.ac.za/SAHA.phtml

Jewkes, R., 2009, 'Understanding men's health and use of violence: Interface of rape and HIV in South Africa', South African Medical Research Council, viewed 20 May 2011, from http://www.mrc.ac.za/gender/reports.htm

Lyotard, J.F., 1984, The postmodern condition: A report on knowledge, University of Minnesota Press, Minneapolis, MN.

Marcia, J.E., 1993, 'The ego Identity Status Approach to Ego Identity', in J.E. Marcia, A.S. Waterman, S.L. Matteson \& J.L. Orlofsky (eds.), Ego Identity: A Handbook for psychosocial research, pp. 3-41, Springer-Verlag, New York, NY.

Mtimkulu, J., 2006, 'Promoting men's involvement in the care and protection of children', Children First 10(64), 38-39.

Müller, J.C., 2005, 'A postfoundationalist, HIV-positive practical theology', Practical Theology in South Africa 20(2), 72-88

Naidoo, K., Matebeni, Z. \& Pietersen-Snyman, M., 2004, 'Challenges and Complexities: Men's responses to HIV and Aids in Winterveld', South African Commonwealth Youth and Development 2(2), 45-63.

Pattison, S., 2000, 'Some Straw for Bricks: A Basic Introduction to Theological Reflection', in J. Pattison \& S. Pattison (eds.), The Blackwell Reader in Pastoral and Practical Theology, pp. 135-146, Blackwell Publishing, Oxford.

Rao Gupta, G., 2002, Gender, Sexuality, and HIV/AIDS: The What, the Why, and the How. Plenary Address for the XIIIth International AIDS Conference, 12 July 2000, Durban, South Africa. International Centre for Research on Women Washington DC, viewed 28 June 2010, from http://siteresources.worldbank.org/ EXTAFRREGTOPGENDER/Resources/durban_speech.pdf

Statistics South Africa, 2010, Mid-year population estimates: Statistical Release P0302, StatsSA, Pretoria, Cape Town.

Struwig, F.W. \& Stead, G.B., 2007, Planning, Designing and Reporting Research, Pearson Education South Africa, Cape Town.

UNAIDS, 2010, UNAIDS report on the global AIDS epidemic, viewed 20 May 2011, from http://www.unaids.org/globalreport/Global_report.htm

Van Huyssteen, W., 1999, The shaping of rationality: Towards interdisciplinarity in theology and science, Eerdmans Publishing Company, Grand Rapids, MN.

Whitley, B.E., 2002, Principles of research in behavioral science, 2nd edn., McGrawHill, New York, NY. 